\title{
The archetypal mandala: Visions of the self in the poetry of Coleridge, Eliot and Breytenbach
}

\begin{abstract}
This paper is a preliminary survey of the visions of the self in poetry. It is concerned with the transformation of consciousness as depicted by each of the three poets a Romantic, a Modernist and a Postmodernist poet respectively and expressed in specific poems with a cyclical nature. The romantic poet Coleridge's "The Rime of the Ancient Mariner" is taken as the first example. It is found to be an allegory of the metamorphosis of the poet's temporal subjective consciousness into an 'eternal' subject position in the narrated text. Liliot's "Four Quartets" exemplifies the Modernist mode of consciousness as an 'anironic vision of unity' achieved by adhering to a religio-aesthetic meta-narrative. Breytenhach (1988:115) calls his volumes of prison poetry "The Undanced Dance". Taken as a whole "The Undanced Dance" has a structure which concurs with wat Brodey (1971:-1) calls "an Einsteinian time-space form of relations" and lures its readers into the trap of fallıng into postmodern quantum consciousness ${ }^{1}$.
\end{abstract}

\section{Introduction: Why poetry?}

The topic of this article implies that a self or selves exists in what is mundanely considered in Husserlian terminology to be an "egological life-world, the structure of which is that of thing and the world on one side and thing-consciousness on the other" (Dallmayr, 1981:47). Each of these selves has at its disposal the faculties of consciousness and mind which facilitate a reflexive turning back on and a 'scrutinising' of this so-called self. This is in accordance with the long commitment of Western culture to Descartes' dictum, cogito ergo sum. Taken to extremities, this statement implies an unbridgeable schism between the $I$ and the Other, subject and object, the imer self and nature or outside reality. The self is

1 Analogous to the light waves and particles in the quantum experiment, quantum consciousness is not an either/or mode of being It is simultancously subjective and objective 
locked within itself and cannot be defined or described in terms of any concrete outside references. Begg (1986:47) explains:

It is hardly tenable to use the term 'consciousness' other than as an attribute or a function of the ego which in turn is by its own definition a subject of consciousness.

This interdependency makes defining or describing consciousness or mind "notoriously hard, except in an arbitrarily limited or tautologous manner". However, to quote Megill (1987:16), "art can make objective what the philosophers represent in thought". Thus, in trying to answer questions about reality and about conscious beings existing in reality, philosophy, psychology and even the physical sciences are all returning to "the universal ocean of poetry from which they all started out" (Megill, 1987:17)

All literature has some connection with, or is wholly concerned with what we call life and reality and with subjects or selves that are part of it. In various degrees, these subjects of literature, are either mimetically in accordance with or even fantastically ${ }^{2}$ contrary to the so-called 'ground rules of reality'. However, in the sense of being epiphanies or revelations even the most astounding visions of poets can be potent tools for clarifying the inner workings of the soul.

The visions evoked in poetry are usually symbolical or mythological. With regard to this, it is interesting to note the following remark of one of the great mythoriented writers, Broch (1955:253): "Myth is the archetype of every phenomenal cognition of which the human mind is capable". According to The Oxford Diclionary (1961:432), the natural sciences define the archetype as "an assumed ideal pattern of the fundamental structure of each great division of organised beings". Jungian psychologists speak of archetypes as "forms or images of a collective nature which occur practically all over earth as constituents of myths and at the same time as autochthonous, individual products of unconscious origin" (Campbell, 1971:8). The assumed ideal patterns of the fundamental structures or archetypes of consciousness are thus not vague, undifferentiated ideas, but are shown in terms of myths and symbols in the dreams, visions and creative works of humankind.

Jung (1969:5) stresses the fact that all archetypal visualizations are attempts of the mind to give form to its own psychological inexpressibility. He explains: "The archetype is essentially an unconscious content that is altered by becoming

2 The words fantastic and fantasy are derived from the Greck word phantasia, which means 'to render (something) visible (to the mind)'. It is related to the word epiphany, meaning 'to show or manifest' (Partndge, 1963:199). Whilc fantasy is often mercly defensive or wishfulfilling in purpose, it can also have the visionary function of revelation: 'to render whatcver we call mind visible to itself in analogic form' 
conscious and by being perceived, and it takes its colour from the individual consciousness in which it happens to appear". All typically archetypal symbols of poetic vision can thus be considered to be fundamental structures of mind and consciousness made visible to itself. For this discussion I have chosen to focus on the archetype resembling the Sanskrit mandala ${ }^{3}$, the schematic representation of which is usually a circular construction, often of great complexity. In Jungian psychology, it is the final archetypal symbol of the individuation and transformation of the psyche, aspiring to the wholeness of the self. As previous research has proved, it is also the basic energising structural element or force of cyclical poetry ${ }^{4}$, the connection apparently being that this type of poetry is always thematically concerned with the conscious transformation of a subject ${ }^{5}$. I shall therefore be using a cyclical poem, a poetic cycle and poems from a series with many cyclical characteristics to illustrate my argument. My approach will be literary historical, the reason being the following.

Begg (1986:47) points out that the word consciousness was coined in 1632 "as a cognate form of the ambiguous word, 'conscience', meaning 'knowledge of which one has the testimony within oneself', as used in 'the consciousness of mine own wants"'. He goes on to explain that at this period, nobody questioned the ontological unity of the personality, so that the problem of ego-consciousness versus other varieties simply did not arise. Much has, however, happened in the intervening centuries to erode this monolithic solidity of concept. Jung's own experiences in psychological research for instance lead him to say : “... the real and

Jung (1969:357) gives the following explanation: "Mandala means circle. [The] basic motif is the premonition of a kind of ccntral point within the psyche, to which everything is related and which is itself a source of energy". In its being a 'source of energy', the mandala as this 'central point' very closcly resembles Kristeva's (1984:25) notion of the chora as articulated by the instinctual "drives which are energy charges as well as psychical marks: a non-cxpressive totality formed by the drives and their stases in a motility that is as full of movement as it is regulated"

Analyses by Deudncy (1971:174) of various poctic cycles, for cxamplc Eliot's "Four Quartets", Rilke's "Duineser Elegien", Lcopold's "Verzen 1897" and several Afrikaans poetic cycles, show how the structural clements of cycles secmingly organise and integrate themselves into complex mandala-like pattems. Spitzer (1962:19) denoted this organising phenomenon of litcrature as the "inward life-centre [an] inner form, which gives an account of the whole"

The mandala as energising clement becoming visible in poctry can be likened to the eruption of the chora as a rhythmic grid in poctıc language or as a chromatic grid in painting I refer to Kristeva's (1980:220-222) explanation of the latter: "In a painting, color is pulled from the unconscious into a symbolic order, the unity of the "self" clings to this symbolic ordcr". Thus. far from bcing cmpty of mcaning, "... a mobilc grid (since it is subjective), but outside of semantics. and therefore, ... mere dynamic law, thythm. interval, gesture", ... this "formal" ... grid ... is heavy with 'scmantic latencies' linked to the economy of the subject's constitution within significance" 
authentic psyche is the unconscious, whereas the ego-consciousness can only be regarded as a temporary epiphenomenon" (1966:91). Today, we know that consciousness is not only a relative and mutable experiential condition within the individual psyche, but also a constantly shifting historical phenomenon. For illustrating this historical shift in the visions of poets, I have chosen examples from three consecutive literary historical phases. Romanticism, Modemism and Postmodernism.

\section{Coleridge's metaphors of Being}

Several literary critics comment on Coleridge's recurrent use of a certain figure or metaphor which, in Jungian terms, can be described as a mandala. As early as 1794 it appears in the poem "On Bala Hill":

'Twas a long way and tedious! - to the eye

Tho' fair th' extended Vale, and fair to view

The falling leaves of many a faded hue

That eddy in the wild gus ro moaning by!

(Coleridge, 1912(1966):56)

Throughout the study Coleridge's Poetic Intelligence (Beer, 1977), this figure is referred to as the "eddying figure". Beer (1977:56) explains that awareness was to Coleridge "a power that at every instant goes out of itself and in the same instant retracts and falls back on itself". This eddy of sensibility or consciousness was "illustrated for [Coleridge] by the Pythagorean and Platonic geometricians in the production, or self-evolution of the point into the circle" (57).

Kessler (1979:15) traces the origins of the eddy metaphor to the lifelong conflict between the fixity of mental abstraction and the "disruptive motion of earthly life" that Colendge suffered. In "Dejection: an Ode" Coleridge (1912(1966):362368) dramatises the conflict between mind and nature. The poet uses the metaphor of a coiling viper as a negative mandala ${ }^{7}$ when blaming his habit of mental scepticism, "abstruse research" and "self-circling thinking" (Kessler, 1979:32) for his rift with nature:

Hence, viper thoughts, that coil around my mind.

Reality's dark dream!

(Coledridge, 1912(1966):367).

6 All italics in the lines quoted from the poems of Coleridge, Eliot and Breytenbach are mine

7 Deudney (1971:171) notes that although the mandala usually has the connotation of positive transformation, negative mandalas of degeneration also occur 
In contrast, his wish for the lady to whom the poem was originally addressed ${ }^{8}$, is one of unblemished joy and unity with nature:

Joy lift her spirit, joy attune her voice;

To her may all things live, from pole to pole,

Their life the eddying of her living soul!

(Coleridge, 1912(1966):368).

Kessler (1979:15) considers Coleridge's "eddy" to be "more than an illustrative metaphor". He denotes variants such as "whirlpool", "whirlwind", "the vortex" and "the circle" and contends that "it provides a symbolic pattern, revealing the poet's desire to define Being by means of external nature".

Although the mandala-like eddy in all its recurrent forms enabled Coleridge to express the dynamic interplay of opposites that could, in rare moments, achieve an equilibrium in the physical world, he remained uncertain about the power of poetry to express Being. This uncertainty is revealed in his use of phantom, which like the eddy metaphor, reveals both negative and positive aspects. According to (Kessler, 1979:39) Coleridge intimated that "just as things observed are not things in themselves, so a metaphor drawn from the sensory world is ever in danger of becoming only an appearance, a ghost or a "Phantom"". Both the phantom and the eddy appear as metaphors of Being in Coleridge's "The Rime of the Ancient Mariner".

\section{3. “The Rime of the Ancient Mariner", a Romantic's allegory of 'mind' for ever alienated from reality in repetitive narration}

Coleridge considered his epic poem, "The Rime of the Ancient Mariner", to be an allegory of his own life and battle of emergence as self and poet. Critics agree that this poem, which is a fantasy in the psychological sense, ${ }^{9}$ is the poetic transformation of the personal experiences of the poet. Whalley (1973:161) says:

In it we experience the most intense personal suffering, perplexity, loneliness, longing, horror and fear which bring us along with Coleridge to the fringes of madness and death, to that nightmare land of Life-in-Death.

To Whalley (1973:162) it is not only the crystallisation of the poet's life up to the composition of the poem, but also "an apalling prophecy, fulfilled to a great extent in his life and successfully endorsed by his own hand as time passed". As

8

Sara Hutchinson

9 It is important to notc that "The Rime of the Ancient Marincr" is not an example of fantasy literature, but fantasy induced by artificial means 
such, it uncannily foretells the history of Coleridgde's mind-nature conflict, which was unresolved from beginning to end. Indeed, according to the 1798 edition of the poem,

Never sadder tale was heard

By a man of woman born

(Coleridge, 1912(1966):201).

The story unfolds along the lines of a circular journey, symbolising in each of its stages the various states of mind of Coleridge, the lonely individual addicted to opium, yet endowed with the very special gift of having a creative imagination. The Mariner's setting out to sea can be seen as the poet's own willing exposure to the turbulence of life, even to the extent of using artificial stimulants in his search for consciousness and Being. This agrees with Kessler's (1979:36) observation that "Coleridge demanded that his idea of Being does not exclude life's disruptive motion. When the stream of life meets the counterforce of an artist's will, a fragment of experience may result".

Coleridge, however, doubted the disclosures of nature as much as he doubted "the ability of natural science, natural philosophy, or natural religion to uncover authentic Being" (Kessler, 1979:74). Considering that critics have varying opinions about the Mariner's act of killing the albatross that guided the ship and its crew out of the wildemess of ice and snow, Coleridge's sceptic attitude, together with the fact that the poem stemmed from an artificially induced fantasy, have important circumstantial bearing on the interpretation of the miraculous appearance of the albatross, its strange, almost magical performance and the Mariner's apparently inexplicable deed.

Upon reading the following stanzas, one is struck by the three lines that I italicise:

At length did cross an Albatross,

Thorough the fog it came;

As if it had been a Christian soul,

We hailed it in God's name.

It ate the food it ne'er had eat,

And round and round it flew.

The ice did split with a thunder-fit;

The helmsman steered us through!

(Coleridge, 1912(1966): 189).

Starting with "as if", the first italicised line has a counterfactual meaning. It infers that the albatross is (perhaps) mistakenly seen to be the incarnation of a Christian soul. The second italicised line draws the attention to its unnatural behaviour and the third describes its eddying flight, which, as though by magic, 
caused the ice to split. If one adds to this its domesticated obedience in coming whenever the Mariner called, it can be argued that a sceptical mind, conscious of the psychedelic nature of its visions, would have had reason enough to doubt the 'angel's' authenticity. Did this cause the poet to allow his phantom understanding, the Mariner, to express his own doubt? ${ }^{10}$ Is the killing of the bird thus symbolical of an erroneous and unsuccessful attempt to escape from a negative and deceptive vortex of psychedelic experience and doubt? That the dead bird is hung around the Mariner's neck nevertheless indicates that a sin has been committed.

Kessler (1979:48-49) believes that the albatross is clearly a symbol of true Being. To him "the Mariner's sin is a "corruption of consciousness" for "Coleridge believed that things as well as words have their own life, their own selves, and a symbol is the only means of declaring life (or Being), since it is neither an idea nor an image anchored in "the meanness of matter". He remarks: "When the poet saw the inner life, the self, the Being of that Hawk's ['the albatross's'] unnameable dropping, he recognised what the Mariner should have seen in the albatross but only later learned to see in the watersnakes".

Beer (1974:231) expounds the theory that "The Ancient Mariner" seems to have been written "on the supposition that if one were to deprive a man of all the props which are normally set up by his customary, reinforced perceptions in time and space he might be enabled to see more clearly his place in the nature of things through the terrors involved in that loss". This is what happens to the Mariner after his crime of having perversely doubted Being. Delivered into a nightmare world where time and motion has ceased, "the Mariner finds no solace until he is able to respond to the movement of the moon and feel delight in the play of the watersnakes. When that happens, ... he perceives the link of all life".

Beyond the shadow of the ship,

$[\ldots]$

I watched their rich attire:

Blue, glossy green, and velvet black, they coiled and swam; and every track

Was a flash of golden fire.

O happy living things! no tongue

Their beauty might declare:

A spring of love gushed from my heart, And I blessed them unaware:

10 Speaking on Coleridge's ideas about animal magnetism, Beer (1974:222) notes that Coleridge was forced to distinguish continually in his own mind between the compelling delusive fantasy and the genuine imaginative insight. 
Sure my kind saint took pity on me,

And I blessed them unaware

(Coleridge, 1912(1966):198).

To Bostetter (1973:193), the Mariner's killing of the albatross is a display of power against God and Nature by means of which the Mariner gains the self-obsessive importance of a compulsive raconteur. He says: "The supernatural powers who control the world, concentrate on his punishment and redemption. Two hundred men drop dead because of his act; but he is condemned-and-privileged-to live on". By blessing the snakelike creatures of the sea, he remains the centre of universal attention. The albatross falls from his neck, it starts to rain and angels and spirits accompany him home. He gains superhuman power that enables him to do penance by continually repeating his story:

I pass, like night, from land to land;

1 have strange powers of speech;

That moment that his face 1 see,

I know the man that must hear me:

To him my tale 1 teach

(Coleridge, 1912(1966):208).

Beer (1974:231) remarks "[The Mariner] can renew himself by the catharses of repeated tellings, ... but he cannot restore himself to the central harmony which he was momentarily allowed to glimpse".

The conclusion is that the doomed Mariner represents Coleridge as the poète maudit accursed and alienated yet, in possession of the hallmark of a so-called 'great author': the power of speech to tell his tale and force the world to listen. This is, however, brought about by the complete reversal of one of the most basic ground rules of reality, the inevitability of death. The Mariner is won as possession by the weird woman, Life-in-death, who outwits Death in a game of cards. Mere chance realises for Coleridge a phantom self of life in death through poetry. This is grimly self-satirical. The poem stresses his inability to exist as an undivided self in nature and society. In his discussion of the interpretative function of allegory, Bloomfield (1972:304) mentions the fact that "Coleridge [used] allegory as a bad term and symbolism as a good one". In casting himself in the weird figure of the Mariner as a telier of tales and calling it an allegory, Coleridge seems to be slyly deconstructing the idea of the 'great author' that prevailed in premodernist ${ }^{11}$ criticism

11 I denote as premodernist the era in literary history when criticism was mainly concerncd with 'the great author' Foucault (1979:141) ascribed "the notion of the author [tol a strong moment of individualisation in the history of idcas" 
From our late twentieth century perspective, we may add to the Mariner the 'moral' of not only allegorising Coleridge, but actually grotesquely allegorising all humanity condernned to suffer from the Cartesian split ego upon entering the world of words. Indeed, "To enter language is to be severed from what Lacan calls the 'real', that inaccessible realm which is always beyond the reach of signification, always outside the symbolic order" (Eagleton, 1983:168).

In terns of structuralist literary theory, the persona of the Mariner can be called a subject position representing the abstract poet, by means of which the concrete poet paradoxically obtains life in death. To continue along the lines of this metaphor, we can say that Coleridge succeeded in freezing or even better, congealing his personal moods, emotions and experiences in 'dead' signs of writing on a white page. In doing so, he also ensured being forever 'resurrected' in the minds and the emotions of the readers of the poem. In this sense, "The Rime of the Ancient Mariner" is an allegory of Coleridge's poet-ego, forever caught in a vicious closed cycle of narrated existence. Similarly, the greater part of humanity consists of millions and millions of such created little mental egos, all concurring with what Eagleton (1983:169) denotes as "function[s] or effect[s] of ... subject[s] which [are] always dispersed, never identical with [themselves], strung out along the chains of the discourses [from] which" they are constituted. Contemporary theory thus exposes what Coleridge, as a premodernist romantic, seems intuitively to have known.

\section{Eliot's "Four Quartets": A Modernist's ${ }^{12}$ structural dream of encompassing 'reality'}

Eliot's poetry arose from what he called aboulia, - "loss of will, despair and apathy" (Kurtz, 1989:128). In "Four Quartets" (1969:171-198), his response to this sense of crisis is clearly that which Wilde (1981:30) denotes as the typically Modernist counterposition of an "anironic vision of oneness or fusion". In a gloriously symphonious ${ }^{13}$ collage of structurally integrated circles, he creates a kind of 'eternal' constellation of cycles by means of which to resolve the opposition of subjective consciousness versus objective reality.

The four sections "Burnt Norton", "East Coker", "The Dry Salvages" and "Little Gidding" form separate, yet integrated cycles, the main themes of which are: time

12 According to Wilde (1981: 24-34) Modernism and Postmodernism are united by a common assumption of crises. The Modemist's response to this is to counterpose an "anironic vision of onencss or fusion".

13 The adjective symphonious is used as I wish to draw attention to the distinguishing structural device of word-cehoes that Eliot uses in "Four Quartets" (see Deudney, 1971 25). 
as memory, time as a cyclical pattern, time as flux, and time as the revelation of the meaning of history. This is in accordance with the habitual ego-structuring of human existence in time, and indeed, as Drew (1950:181) points out, all the cyclical quarters "which make up the various 'quarternities' are enclosed within an image of human experience as 'the turning world', which in turn is twofold: there are two co-existent 'spheres of existence', the physical world of perpetual change and the unseen world of inner unchanging pattern". The problem posed by the poems is humanity's involvement in both the physical world and the unseen world and the results of the lack of wholeness. Eliot's solution to this problem is the aesthetic composition of the 'quarternities' in an encompassing poetic cycle, symbolising existence as time. It is a construct which is in full agreement with what Wilde (1981:19) describes as a widespread view of Modernism presenting itself "as a congeries of closed spatial, formally organized works: a series of self-sustaining or organic constructs distantly proclaiming their inherent superiority to the messiness of the world".

This "inherent superiority" is repeatedly brought to attention in each 'quarternity'. It figures prominently in themes introduced and sustained by repetitive phrases denoting an opposition of time, place and manner between the chaotic world and the orderly poetic structure. In the following quotation, chaotic time is denoted by the the phrase "time before and time after":

Here is a place of disaffection

Time before and time after

In the dim light $[\ldots]$

[...] Only a flicker

Over the strained time-ridden faces

Distracted from distraction by distraction

Filled with fancies and empty of meaning

Tumid apathy with no concentration

Men and bits of paper, whirled by the cold wind

That blows before and after time,

Wind in and out of unwholesome lungs

Time before and time after

(Eliot, 1969:173-174).

In contrast, a varying repetition of sentences and words, for instance "all is always now", "in my end is my beginning", "stillness" and "pattem", denote the orderliness of the poetic structure:

Words move, music moves

Only in time; but that which is only living

Can only die. Words, after speech, reach

Into the silence. Only by the form, the pattern,

Can words or music reach 
The stillness, as a Chinese jar still

Moves perpetually in its stillness.

Not the stillness of the violin while the note lasts,

Not that only, but the co-existence.

Or say that the end precedes the beginning,

And the end and the beginning were always there

Before the beginning and after the end.

And all is always now

(Eliot. 1969:175)

The complete cyclical composition of "Four Nuartets" can be schematically represented by the following mandala-like structure of 'simultaneous ${ }^{14}$ cycles'. It gives us an approximated 'visual experience' of Eliot's composition of religioaesthetic orderliness:

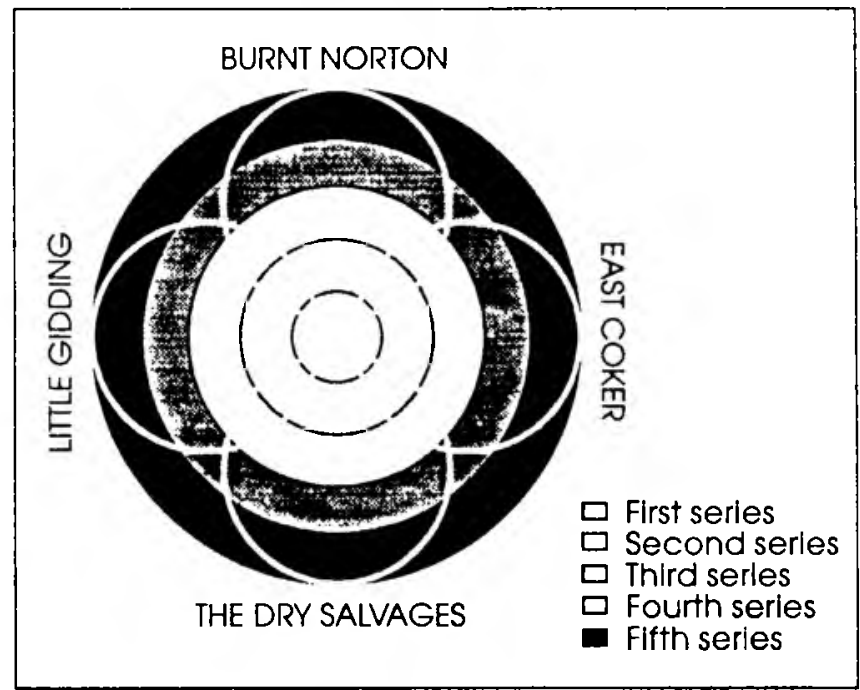

The mandala structure of 'Four Quartets'

This structure is based on what Wilde (1981:21) calls "absolute irony" the conception of equal and opposed possibilities held in a state of total ponse. or the shape of an indestructiblc, unresolvable paradox". In Elıt's Modernist view, however, complexity and paradox subsers itc ultimate goal of aesthetic unity

14 In this type of literary cycle. the progressive development of eycheal clements is "something like that of a sound and a (morc sonorous|ccho that cxist indivisabls in tince" (Deudncs. 1971 172) 
In the words of Cleanth Brooks (1949:195), their intensity guarantees the richness of "an achieved harmony". In "Four Quartets", it becomes

The point of intersection of the timeless

With time, $[\ldots]$

[...] music heard so deeply

That it is not heard at all, but you are the music

While the music lasts

(Eliot, 1969:189-190).

Rather than closing the gap between subjective self and objective reality, the monumental effort of "Four Quartets" concurs with Spanos's (1972:158) description of Symbolist Modemism as "the religio-aesthetic withdrawal from evistential time into the eternal simultaneity of essential art". The aesthetic vision of the whole of human experience is placed within a cosinic outline of Good and Evil presented as "the great dramatic opposition between the way and life of creative, organic order, and the way and death of destructive inorganic disorder" (Drew, 1950:185). Unifying the various stages of thought, biological and social existence, feeling and passion are those moments of sudden insight in which humankind obtains mercy to reconcile and surmount the opposition of the temporal and the eternal. To Eliot, the governing principle of the moments of insight is Incanation, the supreme gift from God to humanity. The following lines refer to such moments

The hint half guessed, the gift half understood, is Incarnation.

Here the impossible union

Of spheres of existence is actual,

Here the past and future

Are conquered, and reconciled,

Where action were otherwise movement

Of that which is only moved

And has in it no source of movement -

Driven by dæmonic, chthonic

Powers

(Eliot, 1969:190).

As a cycle, "Four Quartets" demonstrates how this principle of "Incamation" operates at various levels. It appears in 'hints' and 'guesses' where-and-whenever humankind succeeds in transcending its slavish attachment to time and place. The ultimate perfect 'Incarnation' is that of religion, which in this cycle of poems is embodied in the Anglican creed.

In a typically Modemist anironic fashion, Eliot thus adheres to a meta-nurrative, not only that of religion per se but of religion through art. Equally characteristic of the Modernist mode of consciousness, he does not have any great conlidence in this anironic moment. He sees his art as, at best, an ambignous breakwater against 
the turbid flow of life towards death, adopting an ironic attitude towards the possibilities of order suggested:

[...] Words strain,

Crack and sometimes break, under the burden,

Under the tension, slip, slide, perish,

Decay with imprecision, will not stay in place,

Will not stay still. Shrieking voices

Scolding, mocking, or merely chattering,

Always ecrnil them The Word in the desci.

Is most attacked by voices of temptation,

The crying shadow in the funeral dance,

The loud lament of the disconsolate chimera

(Eliot, 1969:175).

Kurtz (1989:140) contends that "the full prospect of death as the Other, the Unknown as opposed to the Self, is the black hole at the core of the poems". In the liturgical second movement of "The Dry Salvages" the turbid flow of life towards death is symbolically actualised in stanzas that audibly and rliythmically enact the clanging of the bell and the questions and answers of the choir:

Where is there an end of $i$, in sumuriss walling,

The silent withering of autumn flowers [...]

There is no end of it, the voiceless wailing,

No end to the withering of withered flowers,

To the movement of pain that is painless and motionless,

To the drift of the sea and the drifting wreckage,

The bone's prayer to Death its God

(Eliot, 1969:185-186)

The sense of depth or space created by "Four Quartets" is similar to that of "The Hollow Men", which Wilde (1981:22) denotes as "a space of absence, ausence (heing) the figuration of desire, and desire the expressive form both of the poem and of the etemally arrested dialectic that, opening out onto the absence it creates, constitutes its shaping centre".

In all faimess, one has to add that even though the poems are clearly and predominantly contemplative. thus adhering to the nosition of Descartes, "I think, therefore I am', which implies an isolated consciousness, the musical quality and several mantra-like lines of the poems, have the power of evoking fleeting moments in which the 'blind' eyes and 'deaf' ears of the reader become awarc vi ... 
presence of the absent ${ }^{15}$. Eliot intellectually grasped the truth that Breyten Breytenbach practises poetically.

\section{Falling into consciousness: Breyten Breytenbach's "The Undanced Dance"}

The difference between the Modernist Eliot and the Postmodernist Breytenbach can be likened to the difference between the conservatives and the neo-avantgardists: the conservatives establish their being by finding place and value in structures, literary, social, political, and cling to a meta-narrative. The avant-gardist establish their being through an unending push beyond the present limits of the acceptable. For him/her there is narration but no closure in an authoritarian meta-narrative. In Afrikaans poetry, Breytenbach has undoubtedly established himself as a Postmodern neo-avant-gardist and committed exponent of what Russel (1985:238) calls "aesthetic activism, [according to which] literary or artistic innovation is held to be an agent of the transformation of consciousness, articulation, and behaviour in art, life and society". Through his art, he attempts to imagine and possibly provoke a completely changed mode of conscious being.

The poems under discussion for illustrating Breytenbach's aesthetic activism are from Judas Eye and Self-portrait'Death Watch (Breytenbach 1988), which, according to the poet, contains poems 'culled' from a much larger number, originally written in Afrikaans, when he was in prison from September 1975 to December 1982, and since published in four volumes with the collective title "die ongedansde dans" (1988:115). The poet promised that it would consist of five volumes and maintains that he has kept his promise. This has lead to some wild guessing. The obvious answer is that the fifth volume, the forever expanding dance, is a present absence-poetry in the shared mind of all transformatively creative readers of Breyten's work.

To explain Breytenbach's act of transformative creation as well as the act of transfornative and creative reading and to show how it affects consciousness, I refer to a few useful aspects gleaned from De Jong's two articles, "Die blootgestelde leser" 1 and 2 (1983a and 1983b).

Referring to Wolfgang Iser's The Act of Reading, De Jong explains that a poem is a literary experience in which a reader is subjectively involved. The poet specifically structures it for response, thus the text of a poem brings about a scries of subjective processes in the reader. Through this, the poem is realised as an aes-

15 Unusual terms, for instance 'the pocm as a present absence' and the intuitive 'blind cye' and 'deaf ear' of the reader, refer to the metapoetical concepts common to Breytenbach and the Dutch poet Kouwenaar as denoted by Deudney (1991 56-57) 
thetic object. From her argumentation, we can infer that the way in which the readers 'digest' a poem, the meanings they attribute to it and the subjective reactions it evokes in them, become the only mode of existence of the hving poem.

According to her, the reader is also the 'listener' who, while reading, gives voice to certain speech acts, aimed at having a specific effect on readers and listeners alike. The text therefore actually internalises the conditions for its own meaningful realisation, thus also the conditions for transforming the reader's modes of consciousness and perhaps even resulting in pragmatic actions being taken in 'real life'. The logical precondition is that the poet should be the ideal creative 'reader' of the signs of writing into which he systematically and deliberately transposes his life's experiences. Or, expressed differently, in the idiom of Breyten Breytenbach himself, the poet should be the ideal reader of the dead lines of black signs with which life is hanged, gallowed to death on a white page ${ }^{16}$.

As Sartre (1973:125) advises in his essay, "What is Literature?" the poet or writer must find and use linguistic 'traps' in structuring the text. The Afrikaans word for 'trap' is 'val' - a word in which we trace a homonym in the English 'fall'. In Boek I on literary theory, Breytenbach actually says, "Die gedig is 'n val" - "The poem is a fall' (11). Thus he metonymically implies both the trap and the action of falling into it. "Take this gap" is the significant name of the section in which the text of the following poem, "jantra" (Breytenbach, 1988:91), originally appears:

with peaks ever more fair under the mourning snow

my beloved along the mountain passes we'll go

up to the hips in white oblivion

and from the coldest and sharpest-toothed summit

hand in hand (since together we feather wings)

wu wei $w^{\prime \prime u}$ wei ${ }^{17}$ fearlessly plunge

a fall endlessly away to the fertile god-patched valley

now so long greening ago.

A characteristic of Breytenbach's poetry is the way in which words simultaneously take on several meanings. At first glance, "jantra" can be naively read as a poem in which he addresses his absent wife. However, in the complex metonymous interrelation of word meanings in "The Undanced Dance" (Breytenbach, 1988:3-53), the word "beloved" refers not only to wife and mistress but also to

\footnotetext{
16 Sec the powm "(hangpaal cn valluik)" in Lewendood (Breytenbach, 1985:73).

17 Italicised by the poct.
} 
the anima, to death, to the originating motherly womb ${ }^{18}$ of creativity, to poetry itself and eventually to the reader. In the last instance, the speaking 'voice' of 'jantra' is that of the poem itself. It lures the reader into experiencing the white oblivion of the Void by falling into what Breytenbach (1991:66), speaking in the word-pictures of Hou-neng, the sixth Zen patriarch, calls "fire-consciousness".

The text of the poem, "transparenthesis", the name of which means to pass through the pores of the skin/to emerge into knowledge, gives an indication of this experience:

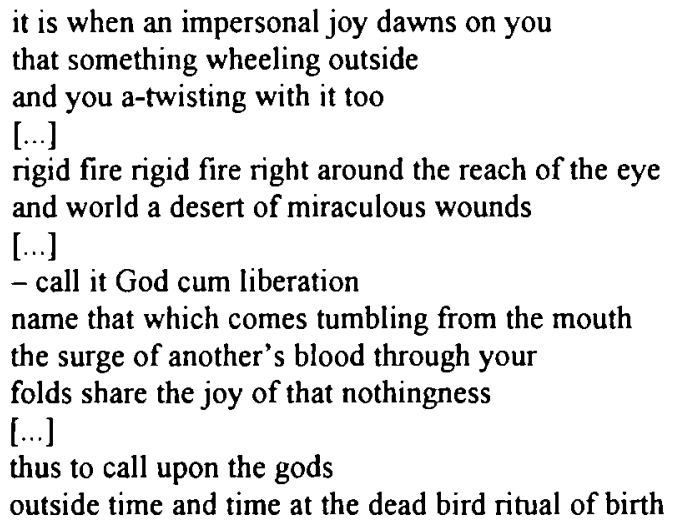

(Breytenbach, 1991:35).

All the poems in Judas Eye and Self-portrait/Death Watch are to both poet and reader a 'free fall' and a falling free from being determined by any restrictive, 'terminal' social and linguistic order. Breytenbach (1988:3) denotes "The Undanced Dance" as "an inside patched with unlimited outside" thus implying some form of remedial work to his/our incomplete moth eaten inner consciences. In Hart-lam, (1991:83) he explains: "It is at this underground level ... where ... artistic creativity and politics ... both can be agents of awareness, of transformation and ... the ... search for putting into motion the joyful despair of metamorphosis. On condition that it be subversive, existential, and without interest or gain". But then, we must take the gap provided by the text that the poet has composed, plunge into it, as it were.

18 The womb of creativity corresponds with what Kristeva denotes as the chora. "the receptacle that Plato calls nourishing and maternal" (Kristeva, 1986:94). As a "receptacle', it is a hollow object similar to those which (Jung, 169:81) associated with "the mother archetype, the uterus, yoni and anything of like shape". Further support for considering the chora to be analogous to the mandala is Jung's pointing out that "becausc of the protection it implies, the magic circle or mandala can be a form of mother archetype" (81) 
Plunging, in whatever sense, implies space into which to fall. The particular space onto which the poetry of Breytenbach and other aesthetic activists, especially among the modern French and Dutch poets, opens, and into which their readers are lured, is that what Mallarme proclaimed to be 'true reality' - the Void, the Absolute, the Unknown Being. Linking psychology and poetry, Kurtz refers to Bion, who has given profound thought to this movement, which he expressed "symbolically as the transformation of $K$ (the realm of knowledge) into $O$ (the thing-in-itself), which is 'been', [requiring] a transitive form of the verb 'to be' rather than apprehended"'19 (Bion, 1965:148).

This transformation that involves "becoming", is a movement towards "ultimate reality, the First Cause, God" (Kurtz, 1989:144-145). However, Bion warns against over-simplifying ' $\mathrm{O}$ ': "it is perhaps too mathematical to call it infinity, too mystical to call it the infinite, too religious to call it the Godhead" (Bion, 1965:150).

Breytenbach cannot be accused of over-simplification. The quest for the Other in his prison poetry is rooted in the exiled jailbird's desire which stems from his experiencing a deficiency of existence almost to the point of deathlike lack of consciousness. In this sense, his poetic visions are escape routes and each of his poems is a trapdoor of escape into 'paradise', that is freedom outside in his own beloved country, an 'erotic' space of jouissance, a desired and desirous mistress, the reader, the poem or death as implicated in the following poems from Judas Eye and Self-portrait/Death Watch (1988): "the commitment" (22), "Isis" (89), "riding song of the bridegroom" (96) and "liberation" (113)

Viewed in the light of his poetics, his poems are also vampire-like entities. As the poet/reader creatively writes/reads, the poem sucks up a life's memories, emotions, knowledge, beliefs and ideals supplanting them by dead black wordsigns, excreted as writing on a page. Visible only to the 'blind' intuitive eye of the reader and audible only to the 'deaf' intuitive ear of the same, the poem, having transformed that which it has devoured into a "landscape of perspectives", provides access to a "present absence" (Deudney, 1991:54-57). By leaving the text of "The Undanced Dance" open, four volumes instead of the five which he had promised, Breyten Breytenbach allows for the freedom of readerly/writerly creation and recreation: the 'fifth volume' as a continual living encounter with the original poems. This is the reader's jouissance, or falling free from the cell of the self into immediate quantum- or fire-consciousness, where subjective and objective being are simultaneously and indivisibly contained in one another.

19 "Reality has to be 'becn": there should be a transitive verb 'to be expressly for use with the term "rcality"' (Bion, 1965:148) 
As far as philosophy is concerned, this 'falling free from the cell of the self' concurs with Heidegger's being-in-the-world which, according to Dallmayr (1981: 103), was 'fleshed' out by Merleau Ponty into "embodiment, no longer seen as the concrete manifestation of a (latent) cogito, but rather as evidence of inherence in the flesh of the world". The writing/reading/existing experience that "The Undanced Dance" exemplifies and into which it was structured to trap readers, is thus not one of esoteric mysticism. It is the practice of living according to a completely down to earth and practical mode of consciousness.

Living in a prison cell, Breytenbach of necessity lived in his mind - a self that he calls a "verdriet-self-tronk", a "misery-self-cell" in the poem, "sept. 1981 mondhorlosie" (Breytenbach, 1984:31-32). Humorous reference is made to this situation. Freely translated it reads

I mean: the way I feel

I can't afford myself ${ }^{20}$

'Taking the gap' of poetry provides an answer. In Hart-lam (Breytenbach, 1991:54) he explains:

The individual creative act is certainly an attempt to make consciousness. This implies drawing on memory. Memory, whether apocryphal or not, provides the feeding ground or the requisite space for the outlining of imagination. Imagination is the biological necessity for inventing a future (54).

Especially noteworthy is the fact that Breytenbach constantly uses terns with a biological or physiological connotation, thus metonymically equating the processes of bodily cycles with the cyclical processes of creative reading and writing. Significantly, he also describes this process of creating a future in terms we associate with attempts of psychoanalysis at concretising the subconscious: "The process is hazardous - but considerations such as free will, intentionality, escapism come into it" (Breytenbach, 1991:54). The route of the process is:

From the Unconscious via the Subconscious to the Conscious, and from there to the Unconscious - and all of the above over the killing fields of reality (Breytenbach, 1991:55).

Breytenbach's metonymous equation of text and body concurs with what Muller (1991:38) denotes as the bioptemic (biological optimising systems), that, being inherent to the processes of Postmodernist texts, generate the topological transformation of the texts. In this sense, the cyclical loops and knots of the following

20 The onginal version is: "ek bedocl: dic way soos ck voel / kan ck myself nie afford nie" (Breytenbach, 1984:32) 
schematised $\log o^{21}$, which appears in each of Breytenbach's books, represents his texts as

... complex structures which are 'lively'-like living structures [... and in which] [a]ny part ... can touch, contact, communicate with, flow with any other part, and the parts, the whole, in time flow through each other .... We have a quality of continuousness in the form and at the same time intracontainment or infolding; we have intrinsic to the form identifiable relationships that are not diadic (inside, outside) but are always at least triadic (context) (Brodey, 1972:4).

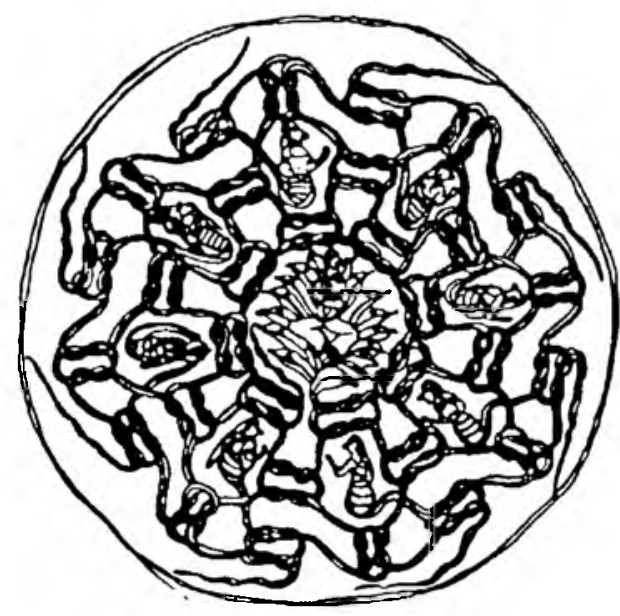

Breytenbach's logo

In the context of "The Undanced Dance", poetry is the mediator between the self and the Other. This finds a philosophically relevant pendant in an aspect that Dalimayr points out in Merleau Ponty's writings, namely his singling out of speech as a faculty that "endlessly renews the mediation between sameness and otherness [for] speech concerns us, catches us directly, seduces us, trails us along, transforms us into the Other and him into us, abolishes the limit between me as subject and the Other as object" (Dallmayr, 1981:103). For 'speech' we may here read 'writing' in the Derridaian sense of the word.

21 This schematic representation should not be interpreted as representing a solitary closed unity. It is a unity and 'closed' only in so far as it is a living and simultaneously dying cell immersed in the flesh of the world 
With the Postmodern cyclical and anti-cyclical narrations, the multiplicity of meanings mirrored and refracted in the word-passages of his prison poetry, Breytenbach invites us into a Zen-like 'biting itself in the tail of the koan'22, the riddle being his poetry and 'reality', until the consciousness is such that it accepts the absurd as the true fabric of life. It is, as Alan Wilde (1981:11) puts it, "suspensive irony: simply accepting the world in all its disorder with a true sense of the randomness of life's moments". Such is the Postmodernist mode of consciousness which underpins Breytenbach's poem "to live is to burn" (1988:110):

all is luminous and all is still: to live is to be digested like this summer-day of loveliness; ever and again to praise the globe rocking by, the sultry leafage of thickets, water-slips, stone-lips, the feathered ones' heart-chips changed to chain-eyes linking silence to silence; how totally rich the mountain, naked, sun-caked - only one plume whitening the wind which soon must bulge slender organ-sounds and streamers; and it is done, spiralling the cycle of seasons has heaved old wrinkles like worms from the lap but look, we are each the coachman of oblivion, rigor mantis with bleached hands at death-cart's reins. Prayer by prayer our way is cocked, cool, a skeleton chaliced in day-dress of flesh ...

burn, burn with me love - to hell with decay! to live is to be alive, while alive to die anyway

(Breytenbach, 1988: 181).

As with the other poems quoted in this article, I offer none but the most cursory of explanations. This is in agreement with Breytenbach's (1991:78-79) own belief that

... the primary confrontation [is] to be between [...] the reader and the image presented, face to face as it were, with neither intermediary nor a priory. The [... poem] as a ... masked messenger, as a reflection of breathing, a continuous shaping of consciousness, can be a weapon also. ... If you can look without projecting a meaning you will be confronted head-on by an embodiment of being.

\section{Conclusion}

By way of conclusion, I wish to highlight two aspects that the poetic visions of Coleridge, Eliot and Breytenbach have in common.

22 A paradox to be mediated upon that is used to train Zen Buddhist monks to abandon ultimate dependence on reason and to force them into gaining sudden intuitive enlightenment 
The first is that in each case the poet is on some kind of quest in search of not only an extended sense of reality but 'Reality' as such, a quest which, in a certain sense, actually entails defeating death.

In his life, Coleridge even used opium for achieving the bliss and horror of an illusory extended existence. His was the nostalgic desire and compensating wish for everlasting life. In 1833 he wrote his own epitaph directing the following request to those who pass by:

\section{O, lift one thought in prayer for S.T.C. ${ }^{23}$ \\ That he who many a year, with toil of breath \\ Found Death in Life, may here find Life in Death!}

(Coleridge, 1966:492)

For Eliot, the quest was his pointing a 'way' and a 'time' in which the 'Incanation' of 'Being' will stop the incessant flux of death and decay, as is concluded at the end of "Little Gidding":

And all shall be well and

All manner of things shall be well

When the tongues of flame are in-folded

Into the crowned knot of fire

And the fire and the rose are one

(Eliot, 1969:189).

Breytenbach's quest can be summed up in the word 'escape', escape from jail and loneliness into 'real life outside', thus escape from being walled in and mastered by the establishment, the 'eye of the I' and from his own 'misery-self-cell' of the ego-self.

The second aspect common to all three can be illustrated by applying as a backdrop to each of the individual quests, the mythical concept of the original fall of mankind and the consequential inevitability of death.

In Coleridge's case, I indulge in a bit of absurd punning on the word fall, all in aid of 'falling into consciousness': Beset by intolerable ordeals every crew member of the Mariner's ship falls as to be expected, "With heavy thump a lifeless lump" (Coleridge, 1912(1966):196). Coleridge's phantom, the Mariner, does not fall with them, but falls prey to Life-in-Death. He lives 'eternally' in the canon of English literature.

In the very last poem of "Four Quartets", Eliot contemplates the desired end of his quest. He relies on " the drawing of this Love and the voice of this Calling"

Note the relevant phonetic resemblance with the noun 'ecstasy'. 
(Eliot, 1969:197), metaphorically denoting both his poetry and God's 'Incarnation', to lead us back "Through the unknown, remembered gate" (197). The culminating image of redemption from our original fall is the fusion of diametric opposites: "And the fire and the rose are one" (198), implying an eventual unity of the mortal embodied self and eternal Spirit.

Breytenbach's fall is poetry. It is the "bird of fancy" (1991:82), instantaneously reversing the original fall. This does, however, not denote an 'eternal' one way passage. As Deleuze and Guattari (1991:40-41) explain in the chapter "Le plan d'immanence" of their book on philosophy, this redemptive movement does not result in fusion:

Ce n'est pas une fusion toutefois, c'est une réversibilité, un échange immédiat, perpétuel, instantané, un éclair. Le mouvement infini est double, et il n'y a qu'un pli de l'un à l'autre 24 .

Contrary to its being merely the product of an emotional and imaginative fantasy of escapism, the 'fall' which is a creative reading/writing act, is also an intellectual structuring discipline. In Hart-lam (1991:54) Breytenbach explains: "Writing is a process and therefore a discipline. It is the discipline of using illusion by the way of capturing the real." In pithy sentences, he, however, applies metonymy or rather his own genial 'trace-speak' to level an ironic deconstructive 'waming':

There comes a point, of course, where true reality is an illusion. You can then call it the illusion of understanding. In due time the two merge. There will be no more dichotomy, no dialectic, and finally one has death. Or one becomes death (Breytenbach, 1991:54-55).

Then he deconstructs the warning: "This does not mean that the writing ceases. On the contrary, one accedes to the homeland of perpetual movement", in which the writing of the self, the text or poem, the body and the cycles of life and death of mortal creatures is a continuous process of transformation.

\section{Bibliography}

Beer, John. 1974. A Stream by Glimpses: Coleridge's Later Imagination. In: Beer, John (ed.) Coleridge's Variety. London : Macmillan. p. 219-242.

Beer, John. 1977. Coleridge's Poetic Intelligence. London : Macmillan.

Begg, Ean 1986. Myth and Today's Consciousness. London: Coventure

Bion, Wilfred R 1984. Transformations London: Karnac.

Bloomfield, Morton. 1972. Allegory as Interpretation. New Literary History, 3(2):301-318 Sept.

24 Freely translated, what they are saying is: 'It is not fusion though, it is a reversibility, a sudden, perpetual, instantancous exchange, a lightning. The endless movement is twofold, the one is layered in the other' 
Bostetter, Edward E 1973. The Nightmare World of The Ancient Mariner. In: Jones, Alun R \& Tydeman, William. (eds). Coleridge:The Ancient Mariner and Other Poems: A Casebook. London: Macmillan p.187-199.

Breytenbach, Breyten. 1984. (' $Y K '$ ') Emmerentia : Taurus.

Breytenbach, Breyten 1985. Lewendood. Emmerentia : Taurus

Breytenbach, Breyten 1987. Boek (deel I). Emmerentia: Taurus.

Breytenbach, Breyten. 1988 Judas Eye and Self-portrait/Deathwatch. London : Faber and Faber

Breytenbach, Breyten. 1991. Hart-lam. Bramley : Taurus.

Broch, Hermann. 1955. The Style of the Mythical Age. In: Dichten und Erkennen. Zürich Rhein

Brodey, Warren. 1972. Biotopology 1972. Radical Software, 4 ; 4-7, Summer

Brooks, Cleanth. 1949. The Well Wrought Urn. London : Macmillan

Campbell, Joseph 1971. The Hero with a Thousand Faces. Princeton, NJ : Princeton University Press.

Coleridge, Ernest. H (ed.) 1912(1966). The Complete Poetical Works of Samuel Taylor Coleridge. Oxford : Oxford University Press.

Dallmayr, Fred R 1981 Tuighlight of Subjectuvity. Amherst : University of Massechusetts Press.

De Jong, Marianne. 1983a Die blootgestelde leser 1. Standpunte 165, 3(2) : 47-64. Apr

De Jong, Marianne 1983b. Die blootgestelde leser 2. Standpunte 165, 3(3):45-61. Jun.

Deleuze, Gilles \& Guattari, Félix 1991. Qe'est-ce que la philosophie? Paris : Minuit.

Deudney, Edna 1971. Die siklus as kompositoriese probleem, met spesiale verwysing na twee siklusse van D.J. Opperman. Johannesburg : Rand Afrikaans University (M.A.thesis )

Deudney, Edna. 1991. Metapoetiese raakpunte in die poesie van Gerrit Kouwenaar en Breyten Breytenbach Literator, 12(2):49-58. Aug.

Drew, Elizabeth. 1950. T.S. Eliot, the Design of his Poetry. London : Eyre \& Spottiswoode.

Eagleton, Terry 1983. Literary Theory. Oxford : Basil Blackwell.

Eliot, Thomas Stearns 1969. The Complete Poems and Plays of T.S. Eliot London: Faber and Faber

Foucault, Michel 1979 What is an Author? In: Harari, Josué V. (ed ). Textual Strategies. London: Methuen. p. 17-72.

Jung, Carl G. 1966. The Practice of Psychotherapy London: Routledge \& Kegan Paul.

Jung, Carl G. 1969. The Archetypes and the Collective Unconscious. London : Routledge \& Kegan Paul

Kessler, Edward. 1979. Coleridge's Metaphors of Being. Princeton, NJ : Princeton University Press.

Kristeva, Julia 1980 Desire in Language: a Semiotic Approach to Literalure and Art Oxford : Basil Blackwell.

Kristeva, Julia 1984. Revolution in Poetic langrage. New York : Columbia University Press.

Kristeva, Julia 1986. The Semiotic Chora Ordering the Drives In: Moi, Toril (ed.) The Kristeva Reader. Oxford : Basil Blackwell

Kurtz, Stephen 1989. The Art of (lnknowing. Princeton, NJ : Aronson.

Megill, Allan. 1987. Prophets of lixtremity. Los Angeles : University of California Press

Muller, Martie 1991. Grondliggende algoritme vir postmodernisme Tydskrif vir literatuurwetenskap, 7(1):38-51

Murray, James A.H. et al. 1961 (eds.). The Oxford English Dictionary. Oxford : Clarendon. Partridge, Eric. 1963. Origins London : Routledge \& Kegan Paul 
Russel, Charles. 1985. Poets, Prophets and Revolutionaries: The Literary Avant-garde from Rimband through Postmodernism. New York : Oxford University Press

Sartre, Jean-Paul. 1973. Politics and Literature. London : Calder \& Boyars.

Spanos, William V. 1972. The Detective and the Boundary: Some Notes on Postmodern Literary Imagination. Boundary, 2(1):158-161, Sept.

Spitzer, Leo. 1962 Linguistics and Literary History. New York : Russel \& Russel

Whalley, George. 1973. The Mariner and the Albatross. In: Jones, Alun R. \& Tydeman, William (eds.). Coleridge: The Ancient Mariner and Other Poems: A Casebook. London : Macmillan. p.160-183

Wilde, Alan. 1981. Horizons of Assent. Baltimore : Hopkins.

\section{University of Port Elizabeth}

